\title{
LAJU TANGKAP, HASIL TANGKAPAN MAKSIMUM (MSY), DAN UPAYA OPTIMUM PERIKANAN UDANG DI PERAIRAN LAUT ARAFURA
}

\author{
Badrudin"), Bambang Sumiono"), dan Narida Wirdaningsih")
}

\begin{abstract}
ABSTRAK
Laut Arafura adalah salah satu daerah penangkapan udang yang sangat penting di Indonesia. Meskipun usaha perikanan udang di Laut Arafura sudah dimulai sejak tahun 1960-an, data 'catch' dan 'effort' yang tersedia untuk dianalisis dapat dikatakan masih minimal. Data yang dianalisis berasal dari perusahaan penangkapan yang berbasis di Sorong. Sebagian besar kegiatan penangkapannya dilakukan di sekitar Kepulauan Aru yang secara geografis berada pada posisi $05^{\circ} 00^{\prime}-07^{\circ} 30^{\prime}$ LS dan $133^{\circ} 00-136^{\circ} 00 \mathrm{BT}$. Dari hasil analisis data catch dan effort periode 1991-2000, dengan model exponensial Fox diperoleh dugaan MSY sekitar 28.000 ton (kisaran antara 17.000 - 75.000 ton), dan upaya optimum sekitar 660 (kisaran antara 408-1745) unit kapal pukat udang. Dari data produksi dan jumlah kapal yang berizin dapat diduga bahwa status pemanfaatan sumber daya udang dewasa ini sudah berada di sekitar MSY. Sesuai dengan prinsip pendekatan dengan kehati-hatian dan adanya ketidakpastian dari sifat-sifat sumber daya maka 'titik acuan' pengelolaan hendaknya didasarkan kepada MSY $=17.000$ ton dan $\mathrm{F}_{\mathrm{opt}}=408$ unit kapal pukat udang. Mengingat jumlah kapal pada saat ini sudah mencapai 458 unit langkah pengelolaan hendaknya dipertahankan pada tingkat 'status quo'. Sampai diperolehnya data 'hasil tangkapan per satuan upaya' untuk tahun-tahun mendatang, sebaiknya tidak ada penambahan jumlah kapal penangkap udang yang dialokasikan ke Laut Arafura.
\end{abstract}

ABSTRACT: Catch rates, Maximum Sustainable Yield (MSY) and optimum effort of the shrimp fisheries in the Indonesian Sector of the Arafura Sea. By: Badrudin, Bambang Sumiono, and Narida Wirdaningsih

The Indonesian waters of the Arafura Sea provide an important fishing ground for shrimp. The shrimp resources in this area have been exploited since 1960s. However, data on catch and effort are scarce. The data that we use in this paper are obtained from commercial fishing activities of a Sorongbased shrimp fishing company whose fishing activities are mostly carried out around Aru Islands. Geographically, the shrimp fishing area around Aru Island is located between $05^{\circ} 00^{\prime}-07^{\circ} 30^{\prime} \mathrm{S}$ and $133^{\circ} 00-136^{\circ} 00 \mathrm{E}$. Based on the analysis of catch and effort data of 1991-2000, the estimated MSY using exponential Fox model is around 28,000 tons (range of 17,000 to 75,000 tons) with an optimum effort of 660 (range of 408 to 1,754) units of shrimp trawler. Based on the production data and the number of licensed shrimp trawlers, it is likely that the status of the shrimp fishery in the Indonesian waters of the Arafura Sea has reached the MSY level. Considering the precautionary approach principles and the uncertainties of the analyzed resources, it is suggested that the reference point for management option of the shrimp fishery in this area should be based on the lower limit of both MSY $(=17,000$ tons $)$ and $F_{\text {opt }}(=408$ units of shrimp trawler $)$. As the total numbers of licensed shrimp trawlers have reached 458 units in the area, we suggest that management measures be maintained at the 'status quo' level. In other words, until the catch per unit effort data for the coming years become available, we suggest that no additional effort in terms of shrimp trawlers should be permitted for this area.

KEYWORDS: $\quad$ shrimp fishery, MSY, optimum effort, Arafura Sea

\section{PENDAHULUAN}

Laut Arafura merupakan daerah penyebaran dan penangkapan udang yang sangat penting di Indonesia. Usaha perikanan udang di Laut Arafura sudah dimulai sejak sekitar tahun enam puluhan. Meskipun demikian, data yang lengkap terutama yang menyangkut 'catch' dan 'effort' serta aspekaspek dinamika populasi udang masih kurang Dengan demikian, upaya pengkajian stok sampai dengan saat ini selalu dilakukan melalui aplikasi model produksi surplus.
Secara ekologis, udang merupakan salah satu sumber daya demersal. Karena posisinya sebagai komoditas ekspor perikanan yang utama, kegiatan pengkajian stok biasanya dilakukan secara terpisah dari ikan demersal. Selain itu karakteristik dinamika populasi seperti pola pertumbuhan, yang salah satu siklusnya adalah 'molting', dan mortalitas udang tampak berbeda bila dibandingkan dengan ikan pada umumnya.

Dalam pengkajian stok yang dilakukan untuk kasus di mana data tidak tersedia secara

'Peneliti pada Balai Riset Perikanan Laut, Jakarta 
memadai, sejumlah data yang diperlukan antara lain; hasil tangkapan (catch) yang akurat dan tingkat upaya yang digunakan untuk memperoleh hasil tangkapan tersebut; komposisi panjang per spesies; indeks kelimpahan yang dinyatakan sebagai 'catch per unit effort', baik berasal dari kapal penelitian atau kapal komersial tertentu (Larkin, 1977).

Dengan maksud melakukan 'up dating' estimasi potensi sumber daya ikan di Indonesia, dengan bantuan FAO/DANIDA, pada tahun 1995 telah dilakukan Lokakarya Pengkajian Potensi Sumber daya ikan Indonesia, berdasarkan data yang tersedia dan paling mutakhir yang rangkumannya telah dilaporkan oleh Venema (1996). Selanjutnya dilaporkan bahwa beberapa hal yang memerlukan tinjauan lebih mendalam yang mempengaruhi hasil perhitungan potensi sumber daya ikan tersebut, antara lain adalah; a) stok patungan (shared stock), b) ekstrapolasi dugaan kepadatan stok, c) wilayah penyebaran dan d) kegiatan kapal asing yang mendaratkan hasil tangkapannya di luar wilayah Indonesia. Keempat 'fenomena' tersebut telah menyebabkan hasil perhitungan potensi sumber daya ikan menjadi kurang akurat.

Tulisan ini merupakan hasil analisis data 'catch' dan 'effort' ditujukan untuk memperoleh estimasi 'maximum sustainable yield, MSY' dan 'optimum effort dari sumber daya udang. Hasil pendugaan MSY ini dapat digunakan sebagai salah satu titik acuan bagi langkah-langkah pengelolaan perikanan udang di perairan Laut Arafura. Sebagaimana diketahui bahwa dengan berlakunya Undang-Undang No. 22/1999 tentang Pemerintah Daerah, pengelolaan dari sebagian wilayah Laut Arafura berada di bawah jurisdiksi Pemerintah Daerah Propinsi Maluku dan Papua Barat.

\section{BAHAN DAN METODE}

Data sampel hasil tangkapan merupakan sebagian hasil pengumpulan data 'catch' dan 'effort' dari usaha penangkapan komersial. Data hasil tangkapan udang dan jumlah kapal penangkap periode 1991-2000 diperoleh dari salah satu perusahaan penangkap udang komersial yang berbasis di Sorong. Dari data tersebut diperoleh angka hasil tangkapan per kapal per tahun yang dapat dianggap sebagai CPUE (catch per unit of effort). Data total produksi udang Laut Arafura bersumber dari statistik perikanan Indonesia dari Propinsi Maluku dan Papua Barat. Sesuai dengan Gulland (1993), total effort dapat dihitung dari data total produksi dibagi dengan CPUE untuk masing-masing tahun.
Daerah penangkapan udang meliputi Laut Arafura, yang sebagian besar dilakukan di sekitar Kepulauan Aru. Operasi penangkapan sebagian besar dilakukan pada kedalaman perairan antara 10-100 meter. Dasar perairan pada umumnya adalah lumpur atau lumpur berpasir. Secara geografis daerah penangkapan tersebut terletak pada posisi $05^{\circ} 00^{\prime}-07^{\circ} 30 \mathrm{LS}$ dan $133^{\circ} 00-136^{\circ} 00$ BT.

Dengan asumsi bahwa hasil tangkapan udang tersebut berasal dari satu unit stok, maka dugaan MSY dan upaya optimum dapat diperoleh melalui aplikasi salah satu model produksi surplus, yaitu model 'exponential' Fox (Sparre \& Venema, 1992).

\section{HASIL DAN BAHASAN}

\section{Unit Stok}

Identifikasi unit stok merupakan langkah awal dalam pengkajian stok. Hal ini perlu dilakukan mengingat bahwa kegiatan perikanan akan selalu berubah sejalan dengan waktu. Daerah penangkapan udang Laut Arafura meliputi sub area Aru, Tembaga Pura, Bintuni, dan Dolak. Sebagian hasil tangkapan udang yang didaratkan di wilayah Maluku seperti Dobo, Kei, dan Benjina, dan sebagian lagi di wilayah Propinsi Papua Barat, seperti Sorong, Bintuni, dan Wanam (Dolak). Untuk keperluan 'stock assessment' keseluruhan data produksi yang tercatat dalam statistik perikanan nasional, baik udang yang tercatat di Propinsi Maluku ataupun Irian Jaya, secara operasional diasumsikan sebagai satu unit stok (Gulland 1993). Hal ini dilakukan dengan pertimbangan bahwa daerah penangkapannya sebagian besar dilakukan di Laut Arafura, sedangkan hasil tangkapan dari perairan pantai lainnya seperti muara Sungai Mamberamo, Teluk Cenderawasih, relatif sangat kecil. Selain itu dapat diduga pula bahwa parameter populasi dari udang tersebut relatif tidak berbeda

\section{Hasil Tangkapan, Upaya, dan Laju Tangkap (CPUE)}

Hasil tangkapan, upaya, dan laju tangkap adalah tiga besaran yang berkaitan erat. Jika dua dari ke tiga besaran tersebut dapat diketahui, maka besaran ke tiga dapat dihitung. Badrudin \& Sumiono (2002) melaporkan bahwa dengan menggunakan data catch dan CPUE periode tahun 1975-2000, tampak bahwa tren dari laju tangkap selama periode tersebut hampir mendatar dengan koefisien arah yang positif. Hal ini menunjukkan bahwa dengan menggunakan model produksi surplus, MSY sumber daya udang tersebut belum dapat dihitung. Namun dengan menggunakan data 


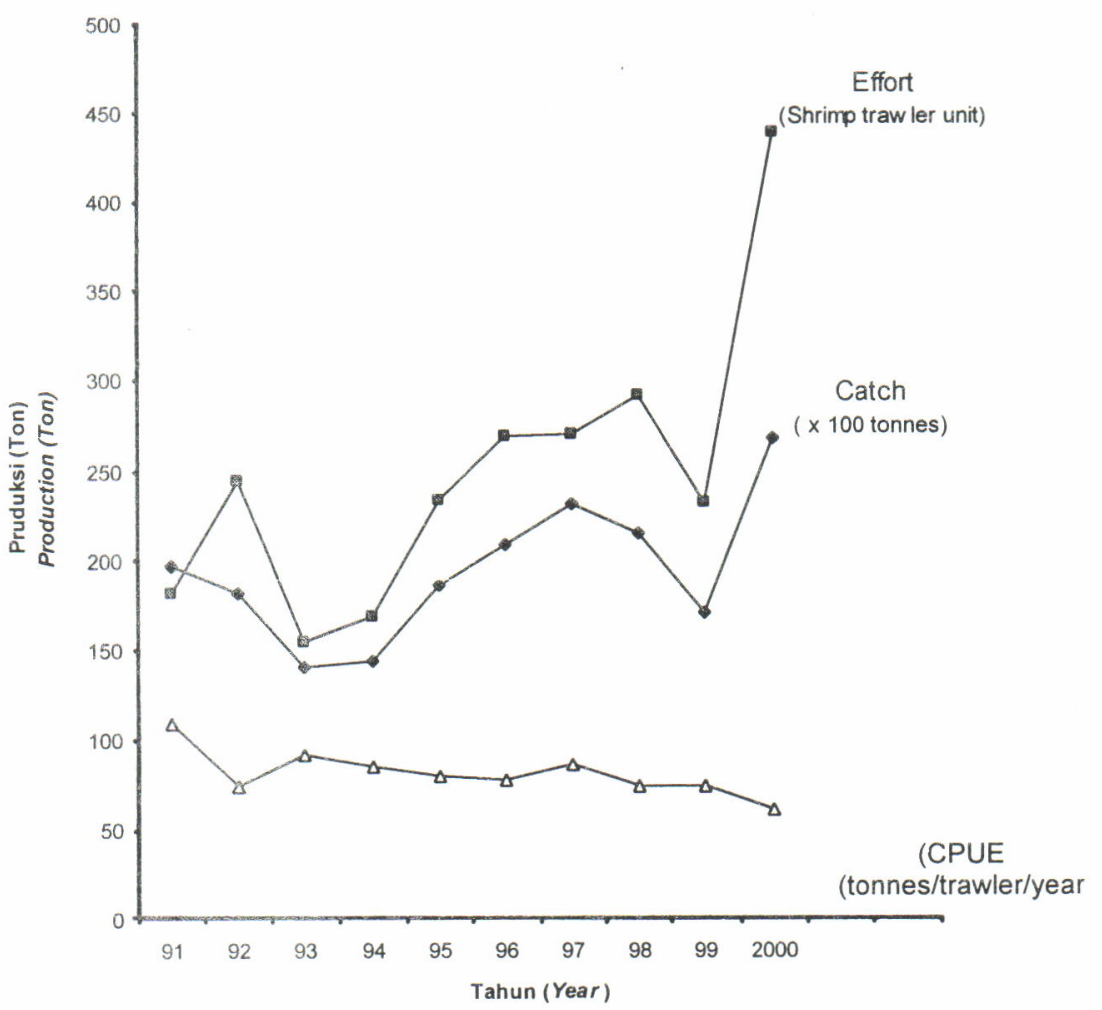

Gambar 1. Tren produksi total, upaya, dan hasil tangkapan per satuan upaya (CPUE) perikanan udang di Laut Arafura (1991-2000).

Figure 1. Trend of catch per unit effort (CPUE) of the shrimp fisheries in Arafura Sea (1991-2000).

tersebut untuk periode 1991-2000, dapat dilihat bahwa tren laju tangkap perikanan udang selama periode tersebut menunjukkan sedikit penurunan (Gambar 1), meskipun masih berada di sekitar rata-rata CPUE. Dengan demikian, koefisien regresi hubungan antara CPUE dengan total effort bersifat negatif, suatu syarat yang diperlukan dalam penghitungan MSY (Sparre \& Venema, 1992). Dengan asumsi bahwa data laju tangkap dari usaha penangkapan komersial tersebut mewakili laju tangkap sumber daya udang di Laut Arafura secara keseluruhan, maka status perikanan udang di Laut Arafura dapat diidentifikasi.

Dari Gambar 1, dapat dilihat bahwa peningkatan jumlah upaya diikuti oleh meningkatnya total hasil tangkapan, akan tetapi diikuti oleh menurunnya hasil tangkapan per satuan upaya. Keadaan seperti ini merupakan fenomena umum yang biasanya terjadi pada suatu stok ikan yang dieksploitasi, sebagaimana pernah terjadi terhadap stok ikan sebelah (plaice) di Laut Utara pada awal abad 19, yang merupakan tonggak sejarah perkembangan ilmu-ilmu pengkajian perikanan (Holden \& Raitt, 1974).

\section{MSY, Upaya Optimum, dan Pengelolaan}

Mengacu kepada Gambar 1, dengan asumsi bahwa 'catchabililty' dari kapal-kapal tersebut adalah sama dan relatif konstan selama periode 1991-2000, tampak bahwa dugaan MSY dengan menggunakan model exponential dari Fox, menghasilkan nilai MSY sekitar 28.000 ton dengan upaya optimum sekitar 660 unit kapal pukat udang (Tabel 1).

Dengan mengacu kepada data statistik nasional periode 1991-2000, tampak bahwa menurut model eksponensial tingkat MSY tersebut belum dilampaui. Meskipun demikian, secara umum dapat diduga bahwa status pemanfaatan sumber daya udang tersebut sudah berada mendekati MSY. Nilai dugaan MSY dan $F_{\text {opt }}$ yang diperoleh dengan menggunakan model eksponensial masing-masing sebesar 28.000 ton dan 660 unit kapal tersebut ternyata berada pada kisaran yang sangat lebar yaitu masing-masing antara 17.000-75.000 ton dan 408-1754 unit kapal pukat udang (Tabel 1, Gambar 2). Sesuai dengan prinsip pendekatan dengan kehati-hatian sebagaimana dikemukakan oleh Rosenberg (1996), akan jauh lebih aman jika titik acuan pengelolaan yang ditetapkan adalah nilai 'lower limit of MSY. Hal ini disebabkan oleh setiap langkah pengelolaan sumber daya ikan harus selalu memperhitungkan adanya berbagai ketidakpastian (uncertainties) dari sumber daya 
Tabel 1. Hasil tangkapan per satuan upaya (CPUE), produksi dan total effort perikanan udang di Laut Arafura

Table 1. Catch per Unit Effort (CPUE), production, and total effort of the shrimp fisheries in Arafura Sea

\begin{tabular}{|c|c|c|c|c|}
\hline \multirow{2}{*}{$\begin{array}{l}\text { Tahun } \\
\text { Year }\end{array}$} & \multirow{2}{*}{$\begin{array}{c}\text { Hasil Tangkapan } \\
\text { (atch }{ }^{1} \text { ) } \\
\text { (tonnes) }\end{array}$} & \multicolumn{2}{|c|}{ CPUE (tonnes/vessel/year) } & \multirow{2}{*}{$\begin{array}{c}\text { Total effort }{ }^{3} \text { ) } \\
\text { (vessel) }\end{array}$} \\
\hline & & CPUE $^{2)}$ & Ln CPUE & \\
\hline 1991 & 19.657 & 108,8 & 4,69 & 180,7 \\
\hline 1992 & 18.076 & 74,0 & 4,30 & 244,3 \\
\hline 1993 & 13.990 & 91,1 & 4,51 & 153,6 \\
\hline 1994 & 14.269 & 84,9 & 4,44 & 168,1 \\
\hline 1995 & 18.503 & 79,5 & 4,38 & 232,7 \\
\hline 1996 & 20.780 & 77,2 & 4,35 & 269,2 \\
\hline 1997 & 23.053 & 85,5 & 4,45 & 269,6 \\
\hline 1998 & 21.472 & 73,7 & 4,30 & 291,3 \\
\hline 1999 & 16.976 & 73,3 & 4,29 & 231,6 \\
\hline 2000 & $\left.26.823^{\star}\right)$ & 61,0 & 4,11 & 439,7 \\
\hline \multicolumn{2}{|c|}{ Mean (Std deviation) ( 8 ) } & & & $248,08(81,56873)$ \\
\hline \multicolumn{2}{|c|}{ Intercept (Std deviation) } & & & $4,75695(0,000134)$ \\
\hline \multicolumn{2}{|c|}{ Slope (Std deviation) } & & & $0,00151(0,000408)$ \\
\hline \multicolumn{2}{|c|}{ MSY (tonnes) } & & & $28.356(28.000)$ \\
\hline \multicolumn{2}{|c|}{ Lower limit of MSY } & & & $17.484(17.000)$ \\
\hline \multicolumn{2}{|c|}{ Upper limit of MSY } & & & $75.095(75.000)$ \\
\hline \multicolumn{2}{|c|}{ Optimum effort ( $\left.F_{\text {opt }}\right)$} & & & 662 \\
\hline \multicolumn{2}{|c|}{ Lower limit of $F_{\text {opt }}$} & & & 408 \\
\hline \multicolumn{2}{|c|}{ Upper limit of $F_{\mathrm{opt}}$} & & & 1754 \\
\hline
\end{tabular}

ikan dan lingkungannya (Garcia, 1996; Walter, 1984). Dengan demikian maka titik acuan pengelolaan sumber daya udang di Laut Arafura hendaknya diletakkan pada nilai dugaan MSY = 17.000 ton dengan upaya optimum, $F_{\text {opt }}=408$ unit kapal. Dengan menetapkan titik acuan pada 17.000 ton maka nilai MSY tersebut lebih rendah sekitar $39 \%$. Penurunan tersebut diduga cukup memadai, mengingat bahwa dugaan MSY yang diperoleh dengan model produksi surplus tersebut terlalu tinggi (Larkin, 1977), dan menurut Walters yang dikutip oleh Gillett (2000) tingginya nilai dugaan MSY yang diperoleh dengan model produksi surplus tersebut adalah sekitar $40 \%$.

Tanpa memberikan angka kisaran, Sumiono \& Priyono (1998) menyajikan nilai dugaan MSY pada tahun 1997 sebesar 21.700 ton. Dibandingkan dengan nilai dugaan MSY untuk tahun 2000 ini nilai dugaan tersebut masih pada kisaran normal dari model produksi surplus. Dengan demikian dapat diduga bahwa stok sumber daya udang di perairan Laut Arafura dewasa ini secara kuantitas masih relatif sama dengan kondisi stok udang pada tahun 1995 maupun pada tahun 1997. Yang perlu diperhatikan adalah adanya perubahan komposisi jenis udang yang tertangkap. Adanya perubahan komposisi dalam komunitas merupakan indikasi kuat dari adanya pengaruh ekstrinsik terhadap komunitas tersebut. Pengaruh tersebut dapat bersifat alamiah atau karena kegiatan penangkapan. Kegiatan penangkapan yang intensif, sebagaimana terjadi di perairan Laut Arafura dewasa ini akan mengarah kepada menurunnya populasi ikan dan makin berkurangnya udang berukuran besar yang akhirnya menjurus ke arah over-eksploitasi seperti telah terjadi di perairan Laut Arafura sektor Australia (Ramm et al., 1990). Kondisi seperti itu juga dilaporkan oleh Direktorat Jenderai Perikanan, di mana hasil tangkapan udang per satuan upaya pada kisaran periode yang sama cenderung terus menurun (Widodo et al., 2001). Pada periode 1991-2000, ada perubahan komposisi fluktuasi hasil tangkapan udang di mana persentase udang krosok cenderung makin meningkat, sedangkan udang windu (black tiger) dan udang jerbung cenderung menurun.

Gambaran tentang aplikasi model eksponensial Fox yang merupakan salah satu model produksi surplus tersebut tampak menyiratkan adanya 'optimisme' yaitu seolah-olah masih ada peluang bagi penambahan upaya. Mengingat prinsip pendekatan dengan kehati-hatian penambahan upaya tersebut haruslah dilakukan dengan monitoring yang ketat terhadap hasil tangkapan per satuan upaya. Dari fenomena tersebut diduga akan jauh lebih aman bagi sumber daya udang jika upaya pengelolaan dipertahankan pada tingkat 'status quo'. Dengan kata lain, sampai dengan diperolehnya data produksi dan CPUE udang tahun-tahun mendatang, untuk sementara sebaiknya tidak ada penambahan jumlah upaya. 


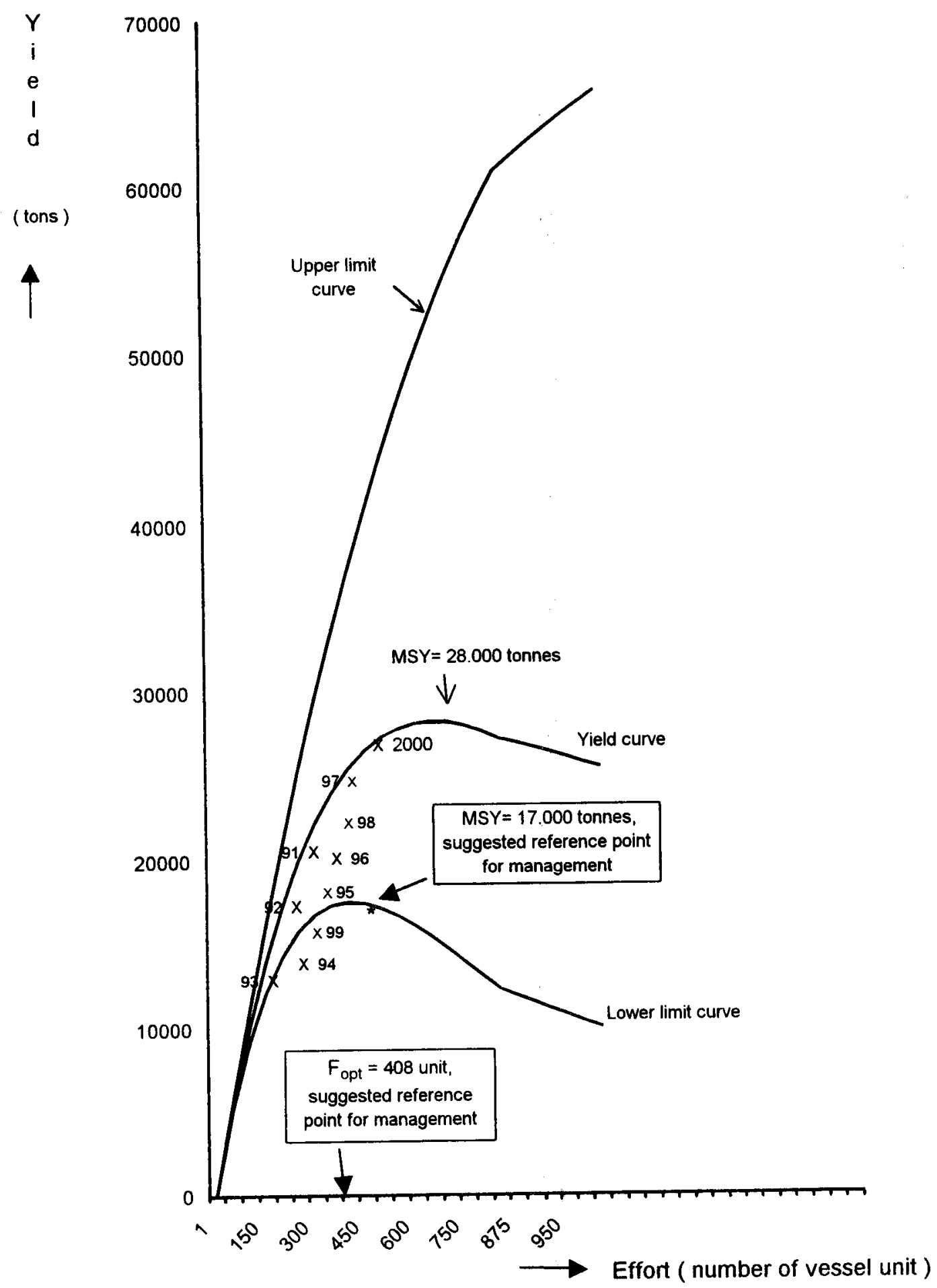

Gambar 2. Hubungan antara hasil tangkapan dengan upaya penangkapan dan posisi MSY serta upaya penangkapan optimum perikanan udang di Laut Arafura (Model eksponensial Fox).

Figure 2. Total yield and total effort relationship and the position of MSY and optimum effort of the Arafura Sea shrimp fisheries (Exponential Fox model).

Banyaknya kapal yang diperlukan untuk memanfaatkan sumber daya ikan dengan tidak merusak kelestarian sumber daya tersebut merupakan pertanyaan sederhana yang perlu diperhatikan. Bagi para pengambil keputusan pengelolaan sumber daya udang di Laut Arafura, adanya penambahan kapal pukat udang di perairan tersebut benar-benar harus diikuti dengan langkah monitoring CPUE secara teratur. Berapa jumlah kapal pukat udang yang sebenarnya 
beroperasi di Laut Arafura dewasa ini (2002) tidak diketahui dengan pasti. Dari Direktorat Jenderal Perikanan Tangkap diperoleh informasi bahwa jumlah kapal pukat udang yang mendapatkan izin usaha adalah sekitar 458 unit. Dengan mengacu kepada model Fox yang lebih optimistik tersebut, diharapkan bahwa jumlah kapal pukat udang pada tahun 2002 ini tidak lebih dari 660 unit, sedangkan menurut Walters vide Gillett (2000) jumlah kapal yang terdaftar unit sebenarnya sudah melebihi 408 unit yang hendaknya dijadikan titik acuan pengelolaan yang lebih bersifat konservatif yang diharapkan dapat menjamin keberlanjutan baik secara ekologi ataupun ekonomi (ecologically and economically sustainable).

Tujuan utama pengelolaan sumber daya udang adalah menentukan tingkat hasil tangkapan yang berlanjut dalam jangka panjang (long-term sustainability). Perencanaan dan pencapaian tujuan dari langkah pengelolaan yang dikembangkan harus dapat mendukung kelancaran implementasi dan menjamin efektifitas bagi tiap langkah pengelolaan yang diterapkan. Dari kegiatan tersebut akan terbuka kesempatan dan langkah yang jelas yang harus diadopsi, yaitu pemantauan jumlah kapal dan hasil tangkapan, pengumpulan dan pemanfaatan data, pemantauan-pengendalian-pengawasan (MCS), yang kesemuanya ditujukan untuk menjamin keberlanjutan pemanfaatan stok udang yang ada

Menetapkan 'length at first capture' dikaitkan dengan 'length at first maturity' hendaknya dirancang dalam rangka meningkatkan rekruitmen, yaitu memberikan kesempatan kepada udang untuk tumbuh ke arah umur/panjang yang lebih dekat kepada puncak pertumbuhan biomassa. Diperolehnya informasi tentang tingkat kematangan gonad diarahkan untuk pendugaan panjang saat pertama matang gonad, Lm (length at first maturity) dan dugaan musim pemijahan.

Langkah selanjutnya adalah menetapkan pembatasan alat tangkap (gear limitation). Terhadap kapal-kapal penangkapan skala industri yang menggunakan jaring, harus ditetapkan penggunaan 'minimum mesh size' dan ukuran alatjaring yang digunakan. Sampai dengan saat ini, tampaknya belum ada upaya-upaya pemerintah untuk menegakkan peraturan tentang ukuran mata jaring minimum tersebut. Selain itu semua jenis kapal dan alat tangkap yang dioperasikan dan ditujukan untuk menangkap udang harus mempunyai izin yang diberikan bersamaan dengan daftar kewajiban-kewajiban yang harus dipenuhi (antara lain: mengisi log book, dan mengembalikannya kepada pemberi izin). Beberapa jenis alat tangkap tertentu yang tidak selektif harus dibatasi penggunaannya
Populasi yuwana udang biasanya berada di sekitar perairan pantai sampai kedalaman sekitar 10 meter. Dengan demikian, maka pada bulanbulan tertentu akan lebih bijaksana apabila Pemerintah Daerah melakukan upaya penutupan kawasan tersebut dari kegiatan penangkapan. Untuk itu, pengawasan oleh masyarakat pantai terhadap kegiatan tersebut diduga merupakan cara yang paling efektif

\section{KESIMPULAN DAN SARAN}

\section{Kesimpulan}

1. Selama periode penelitian ini persentase udang krosok cenderung naik sedangkan udang windu dan udang jerbung (banana shrimp) cenderung menurun.

2. Hasil analisis data catch dan effort periode 1991-2000, menunjukkan bahwa trend laju tangkap sumber daya udang selama periode tersebut sedikit menurun.

3. Baik nilai dugaan MSY ataupun $F_{\text {opt }}$ yang diperoleh melalui aplikasi model exponential mempunyai kisaran yang sangat lebar, yaitu $M S Y=28.000$ ton (kisaran 17.000-75.000 ton dan $F_{\text {opt }}=660$ (kisaran 408-1754) unit kapal pukat udang

\section{Saran}

1. Sesuai dengan prinsip pendekatan dengan kehati-hatian, akan jauh lebih aman jika titik acuan pengelolaan yang ditetapkan adalah nilai "lower limit of MSY. Hal ini disebabkan oleh adanya sifat ketidakpastian yang tinggi dari parameter sumber daya ikan dan lingkungannya. Dengan demikian maka titik acuan pengelolaan sumber daya udang di Laut Arafura hendaknya diletakkan pada nilai dugaan $\mathrm{MSY}=17.000$ ton dengan upaya optimum, $F_{\text {opt }}=408$ unit kapal.

2. Sampai dengan diperolehnya data produksi dan CPUE udang untuk tahun-tahun mendatang, untuk sementara sebaiknya tidak ada penambahan jumlah kapal, atau dipertahankan pada tingkat 'status quo', yaitu sebanyak 458 unit.

\section{UCAPAN TERIMA KASIH}

Dalam kesempatan ini penulis mengucapkan banyak terima kasih kepada Direksi PT. Dwi Bina Utama baik di Jakarta ataupun di Sorong, yang telah memperkenankan kami untuk menganaiisis 
data hasil tangkapan udang yang diperoleh perusahaannya. Semoga hasil analisis ini merupakan informasi awal bagi langkah-langkah pengelolaan berupa hasil tangkapan yang optimal dan berlanjut.

\section{DAFTAR PUSTAKA}

Anonymous. 1993-2001. Statistik perikanan Indonesia. Direktorat Jenderal Perikanan. Jakarta.

Badrudin \& Sumiono, B. 2002. Indeks kelimpahan stok dan proporsi udang dalai komunitas sumber daya demersal di perairan Kepulauan Aru, Laut Arafuru. Jurnal Penelitian Perikanan Indonesia Edisi Sumber Daya dan Penangkapan VIII(1): 96--102.

Garcia, S.M. 1996. The precautionary approach to fisheries and its implication for fisheries research, technology and management. An updated review. FAO Precautionary approach to fisheries. Part 2. Scientific Papers. FAO Fish.Tech.Paper. No. 350. Part 2: 1--75. FAO Rome.

Gillett, R. 2000. Report of the fisheries management specialist. Assistance in Marine Fisheries Legislation. TCP/INS/8922. FAO-UN. Rome.

Gulland, J.A. 1993. Fish stock assessment. A Manual of Basic Methods. John Wiley \& Sons.

Holden, M.J., \& D.F.S.Raitt (eds). 1974. Manual of fisheries science. Part 2. Methods of Resource Investigations and their Application. FAO Fish. Tech. Pap. (115) Rev. 1. 214 hal.

Larkin, P., 1977. An epitaph of the concept of Maximum Sustainable Yield. Trans. Amer. Fish. Soc. 106: 1--11.

Ramm, D.C., P.J.Pender, R.S.Willing, \&
R.C.Buckworth., 1990. Large-scale spatial pattern of abundance within the assemblage of fish caught by prawn trawlers in Northern Australian Waters. Austr. J.Mar. and Freshwater Res., 1990, 41:79--95.

Rosenberg, A.A. \& V.R. Restrepo., 1996. Precautionary management reference points and management strategies. An updated review. FAO Precautionary Approach to Fisheries. Part 2. Scientific Papers. FAO Fish.Tech. Paper. No. 350. Part 2: 129--140. FAO Rome.

Sparre, P. \& S.C.Venema. 1992. Introduction to tropical fish stock assessment. FAO Fish. Tech.Paper. No. 361/1.

Sumiono, B., \& B.E.Priyono. 1998. Sumber daya udang penaeid dan krustasea lainnya. In: Widodo, J., K.A. Azis, B.E.Priyono, G.H. Tampubolon, N. Naamin dan A.Djamali (Eds). Potensi dan Penyebaran Sumber Daya Ikan Laut di Perairan Indonesia. Komisi Nasional Pengkajian Stok Sumber Daya Ikan Laut - LIPI.

Venema, S.C.(ed.). 1996. Report on the INDONESIA/FAO/DANIDA workshop on the assessment of the potential of the marine fishery resources in Indonesia. Denmark fund in trust. FI:GCP/INT/ 575/DEN. Report Activity No. 15. FAO-UN.Rome.

Walters, C.J. 1984. Managing fisheries under biological uncertainty. In R.M.May (Ed). Exploitation of Marine Communities. Report of the Dahlem Workshop on the Exploitation of Marine Communities. Springer-Verlag. Berlin. Hal: 263--274.

Widodo, J., Purwanto \& S.Nurhakim (Eds). 2001 Evaluasi penangkapan ikan di perairan ZEEl Arafura. Pengkajian Sumber daya Ikan Demersal. Direktorat Jenderal Perikanan Departemen Kelautan dan Perikanan. 50 hal 
